\title{
Inzulinrezisztencia és következményei gyermek- és serdülőkorban
}

\author{
Tobisch Borbála dr. ${ }^{1,2}$ - Blatniczky László dr. ${ }^{1}$ - Schusterova Ingrid dr. ${ }^{3}$ \\ Kovács Levente dr. ${ }^{4}$. Barkai László dr. ${ }^{2,3,4,5}$ \\ 'Észak-Közép-budai Centrum, Új Szent János Kórház és Szakrendelő, Budapest \\ ${ }^{2}$ Debreceni Egyetem, Egészségtudományok Doktori Iskola, Debrecen \\ ${ }^{3}$ Kassai P. J. Šafárik Egyetem, Általános Orvostudományi Kar, Gyermekgyógyászati Klinika, Kassa, Szlovákia \\ ${ }^{4}$ Óbudai Egyetem, Élettani Szabályozások Kutatóközpont, Budapest \\ ${ }^{5}$ Miskolci Egyetem, Egészségügyi Kar, Elméleti Egészségtudományi Intézet, Miskolc
}

\begin{abstract}
Számos adat igazolja, hogy az inzulinrezisztencia gyakori jelenség gyermek- és serdülókorban, és szoros kapcsolatban áll a cardiovascularis kockázat növekedésével, ami miatt a kérdéskörre az életnek ebben a korai szakaszában is kiemelt figyelmet kell fordítani. Ma már egyre több ismerettel rendelkezünk a kockázati tényezőket illetően, nincs azonban egységes álláspont az inzulinrezisztencia meghatározására vonatkozóan a klinikai gyakorlatban, és nem rendelkezünk megfelelő laboratóriumi markerekkel, melyek segítségével a veszélyeztetetteket széles körben eredményesen lehetne azonosítani. Mindezek alapján a laboratóriumi módszerrel történő szúrés ebben az életkorban nem indokolt, azonban a társuló és következményes kórállapotok klinikai alapon történő felismerésére törekedni kell. A cardiovascularis kockázat megelőzésére irányuló életmódbeli prevenció hatásos az inzulinrezisztencia csökkentésében, a gyakorlatban azonban kivitelezése és eredményessége korlátozott. A gyógyszeres intervenció jelenleg ebben az életkorban csak egyes szelektált esetekben kerülhet alkalmazásra. További klinikai kutatásokra van szükség az inzulinrezisztencia mérése, az életmódbeli és gyógyszeres intervenciós lehetőségek területén annak érdekében, hogy sikeres stratégiák legyenek kialakíthatók a cardiovascularis halálozás megelőzése, csökkentése érdekében.
\end{abstract}

Orv Hetil. 2021; 162(11): 403-412.

Kulcsszavak: inzulinrezisztencia, metabolikus szindróma, cardiovascularis rizikó, diabetes, gyermekkor

\section{Insulin resistance and its effects in children and adolescents}

Numerous data confirm that insulin resistance is a common phenomenon in children, and closely links to an increase in cardiovascular risk, therefore it is urgent to pay attention to this from early childhood. Today, we have more and more knowledge about risk factors, but there is no common position on the definition of insulin resistance in clinical practice and we do not have adequate laboratory markers to identify those at risk effectively. Based on all these factors, laboratory screening is not justified at this age, however, efforts should be made to recognize associated and consequent conditions on a clinical basis. Lifestyle prevention to prevent cardiovascular risk is effective in reducing insulin resistance, but in practice its implementation and effectiveness are limited. At present, pharmacological intervention can only be used in certain selected cases with this age group. Further clinical research is needed to measure insulin resistance, lifestyle and drug intervention options in order to develop successful strategies to prevent and reduce cardiovascular death.

Keywords: insulin resistance, metabolic syndrome, cardiovascular risk, diabetes, childhood

Tobisch B, Blatniczky L, Schusterova I, Kovács L, Barkai L. [Insulin resistance and its effects in children and adolescents]. Orv Hetil. 2021; 162(11): 403-412.

(Beérkezett: 2020. augusztus 31.; elfogadva: 2020. szeptember 29.)

\section{Rövidítések}

$\mathrm{AAP}=($ American Academy of Pediatrics $)$ Amerikai Gyermekgyógyászati Akadémia; BMI = (body mass index $)$ testtömegindex; DPP4 = dipeptidil-peptidáz-4; EMA = $($ European Medi- cines Agency) Európai Gyógyszerügynökség; FDA = (U. S. Food and Drug Administration) az Amerikai Egyesült Államok Élelmiszer-biztonsági és Gyógyszerészeti Hivatala; GLP1 = (glucagon-like peptide 1 ) glükagonszerú peptid-1; $\mathrm{Hb}_{\mathrm{Alc}}=$ 
hemoglobin-A-1c (glikált hemoglobin); HDL-C = (high-density lipoprotein cholesterol) magas sürüségú lipoprotein-koleszterin; HOMA = (homeostasis modell assessment) homeosztázismodell értékelése; HOMA-IR = (homeostatic model assessment of insulin resistance) az éhgyomri vércukor- és inzulinszintértékekből számított inzulinrezisztencia-index; IDEFICS $=$ (Identification and prevention of Dietary- and lifestyle-induced health EFfects In Children and infantS) az étrendből és életmódból eredő egészségkárosító hatások azonosítása és megelőzése gyermekeknél és csecsemóknél; IDF = (International Diabetes Federation) Nemzetközi Diabetes Szövetség; IL-6 = interleukin-6; ISI = inzulinszenzitivitási index; LDL = (low-density lipoprotein $)$ alacsony sűrűségú lipoprotein; NAFLD = (non-alcoholic fatty liver disease $)$ nem alkoholos májsteatosis; OGTT = orális glükóztolerancia-teszt; PAIl = plazminogénaktivátorinhibitor $-1 ; \operatorname{PCOS}=$ polycystás ovarium szindróma; QUICKI = (quantitative insulin sensitivity check index) kvantitatív inzulinérzékenység-ellenőrző index; SGLT $=$ (sodium glucose co-transporter) nátrium-glükózkotranszporter; $\mathrm{T} 2 \mathrm{DM}=$ (type 2 diabetes mellitus) 2 -es típusú diabetes mellitus; TÁMOP = Társadalmi Megújulás Operatív Program; WBISI = (whole body insulin sensitivity index $)$ teljestest-inzulinszenzitivitási index

Az elhízás jelenkorunk egyik legnagyobb népegészségügyi kihívása, és az elhízott gyermekek száma közismerten világszerte nő. Az inzulinrezisztencia az elhízáshoz társuló leggyakoribb metabolikus elváltozás, amely központi szerepet játszik az elhízáshoz társuló egyéb, komoly jelentőséggel bíró elváltozásoknak, mint például a cardiovascularis rizikónak a megjelenésében [1]. Az inzulinrezisztencia és az ahhoz társuló állapotok korai felismerése gyermekkorban fontos lenne a veszélyeztetettek kiemelése és a következmények szekunder, tercier prevenciója szempontjából. Ebben az életkorban azonban nem egységes a kórállapot megítélése, de a kivizsgálás menete, illetve módszerei sem, ugyanis a felnőttek esetében használatos diagnosztikai lehetőségek csak részben alkalmasak olyan gyermekkori vizsgálatok kivitelezésére, melyekből használható következtetéseket vonhatnánk le a gyakorlat számára [2-8]. Hasonlóképpen problémát jelent az inzulinrezisztenciával leggyakrabban társuló klinikai entitásnak, a metabolikus szindrómának a meghatározása gyermekkorban, hiszen a felnőttkorban sem egységes kritériumrendszerek is számos vitára adnak okot [9]. Egy azonban bizonyos: az elhízás mellett a metabolikus szindróma fő komponenseinek időben történő felismerése gyermekkorban is fontos lenne, mert az ilyen eltéréseket mutató fiatalok cardiovascularisan veszélyeztetettek, szemben az „egészséges” elhízottakkal.

Közleményünk összefoglalja az inzulinrezisztenciával és következményeivel összefüggő jelenlegi ismereteket, melyek gyermekgyógyászati vonatkozásban fontosak a kórállapotok kifejlődése szempontjából, illetve ráirányíthatják a figyelmet a korai felismerés, megelözés és esetleges kezelés jelentőségére, gyakorlati lehetőségeire.

\section{Az inzulinrezisztencia fogalma, kórélettani összefüggései}

Az inzulinrezisztencia kórélettani értelemben a szövetek csökkent válaszkészsége az inzulin mediálta celluláris folyamatokra. A legismertebb és messze a leggyakoribb oka a zsírszövet túlzott felszaporodása, ám nem minden elhízásban látunk inzulinrezisztenciát, és azt is tudjuk, hogy normál súlyú egyénekben is megjelenhet [9]. Ismert további állapotok a szteroid- és növekedésihormon-kezelések, illetve ritka genetikai defektusok talaján kialakuló inzulinrezisztens állapotok, melyek lényegesen ritkábban fordulnak elő a klinikai gyakorlatban. Az utóbbiak primeren az inzulinreceptor vagy szignálmechanizmusban részt vevő proteineket kódoló géneket (INSR, $A K T 2$ stb.), a zsírszövet fejlődésében szerepet játszó géneket (MC4R, AGPAT2, PPARG stb.) érintik, illetve úgynevezett ciliopathia talaján kialakuló komplex genetikai szindrómákat okoznak (Alström/ALMS1, BardetBiedl/BBS1-BBS18 stb.) [10]. A pubertás ismert módon önmagában is fiziológiás, átmeneti inzulinrezisztenciát okoz [11], melynek következtében az inzulinszintek a serdülés folyamatának első szakaszában emelkedő értékeket mutatnak, majd annak lezajlásával csökkennek [11].

Ismert, hogy az inzulinreguláció zavara központi szerepet játszik az összetett anyagcsere-eltérések kialakulásában, a metabolikus szindróma megjelenésében és a cardiovascularis rizikó fokozásában. Az inzulinrezisztencia összességében már gyermekkorban is fokozza a cardiovascularis betegségek és a 2 -es típusú diabetes mellitus (T2DM) megjelenésének rizikóját azáltal, hogy jelenlétében igazolható módon hyperglykaemia, hypertriglyceridaemia, csökkent HDL-C-szint és magas vérnyomás alakul ki. Az inzulinnak a glükózhomeosztázisra kifejtett hatását elsődlegesen a májon, az izomszöveten és a zsírszöveten keresztül fejti ki. A májban csökkenti a glükózprodukciót, növeli a glikogénraktárakat, fokozza az izom- és zsírszövetek glükózfelvételét [12]. Felelős a sejtek adipocytairányú differenciálódásáért, melyek a proinflammatorikus citokinek termelését serkentik, továbbá az ovariumok androgéntermeléséért és a vese nátrium-visszatartásának fokozásáért. Mindezen hatásokat a 19-es kromoszómán lokalizált transzmembrán proteinreceptoron keresztül éri el, amelynek extracelluláris alfaalegysége köti az inzulint, a transzmembrán béta-alegység pedig beindítja az intracelluláris tirozin-kináz-aktiválódást, és ezzel foszforilációs láncolatot generál [13].

Az inzulin többféle mechanizmuson keresztül emeli a vérnyomást, a már említett nátrium-visszatartáson, a szimpatikus aktivitás fokozásán, valamint az inzulin stimulálta simaizomszövet-növekedésen keresztül [14]. Ismert feltételezés, hogy a metabolikus szindróma kulcsszereplője az inzulinrezisztencia, és ez lenne felelős az elhízás és a cardiovascularis rizikó összefüggéséért a gyermekkorban is [1]. 'Clamp' technikás vizsgálatok 
szerint az inzulinrezisztencia oka elsősorban az izomszövetek válaszkészségében kereshető, hiszen a glükózfelvétel 75\%-áért az izomzat felelős, míg a zsírszövet csupán 2-3\%-ban játszik ebben szerepet [15]. A hyperinsulinaemia serkenti a lipolitikus gének transzkripcióját, így emelkedik a triglicerid szintézise. Az inzulinrezisztencia klinikai megjelenésének pontos mechanizmusai továbbra sem ismertek, feltételezések szerint a magas inzulinszint specifikus, inzulin által kiváltott mechanizmusokon keresztül vezet az acanthosis nigricans, a polycystás ovarium szindróma (PCOS), az akcelerált növekedés és a prematurus adrenarche megjelenéséhez [9, 16]. Ezt támasztják alá olyan tanulmányok, melyekben mutáns inzulinreceptort hordozó egyénekben magas inzulinszintek mellett szintén jelentkeztek ezek a klinikai megjelenési formák, miközben nem mutatták az inzulinanyagcsere-zavarokra jellemző egyéb elváltozásokat, nem volt eltérés a triglicerid- és a HDL-C-szintekben, nem alakult ki májsteatosis, és az adiponektinszintek is normálértékeket mutattak [9].

\section{Rizikófaktorok}

Az elmúlt években számos adatot publikáltak, melyek egyértelmúen körvonalazták az inzulinrezisztencia megjelenésére utaló rizikófaktorokat: ilyen kockázati tényezők az elhízás mellett a zsírszövet lokalizációja, mint a visceralis és hepaticus zsírlerakódás, a mozgásszegény életmód, táplálkozási tényezők, PCOS, egyes genetikai faktorok és familiáris halmozódás, az anya terhességgel szövődött diabetese, az etnikai hovatartozás, a pubertás, a kis születési súly és a postnatalis és gyermekkori súlygyarapodás üteme. Ezek közül az utóbbi időben a gyermekkor vonatkozásában a legtöbb figyelem az etnikumra, a pubertásra, a születési súlyra, valamint a postnatalis és gyermekkori súlygyarapodásra irányult.

A pubertás alatt a fiziológiásnak tekinthető inzulinrezisztencia következményeként az inzulinszintekben jelentős emelkedés következik be, ami egyéb kockázati tényezők jelenléte esetén (elsősorban túlsúly) a kóros anyagcsere-folyamatok (metabolikus szindróma) kiindulópontja lehet [17]. A kaukázusi etnikumhoz képest egyes népcsoportokban (afrikai, pima indián, hispán, ázsiai) a gyermekek inzulinérzékenysége alacsonyabb $[18,19]$.

A pubertás során azonban a kompenzatorikus hyperinsulinaemia ezen etnikumokban kisebb mértékú, emiatt esetükben a szénhidrát-anyagcsere zavara gyakrabban alakulhat ki a serdülőkor időszakában. Ez a jelenség öszszefüggésben lehet az egyes népcsoportokban felnőttkorban jól dokumentált T2DM-prevalencia eltéréseivel [20]. Bizonyos genetikai eltérések is rizikófaktorként jelentkeznek [14]. Ikertanulmányok bizonyítják a genetikai tényezők szerepét a serdülőkori inzulinrezisztencia megjelenésében. A felmenőik közt T2DM-el rendelkező, de egészséges serdülők inzulinrezisztensebbek, mint társaik, illetve védő jellegü gének (például a Prol2 Ala gén) is leírásra kerültek, melyek jelenlétében a kaukázusi gyermekek inzulinszenzitívebbnek bizonyultak, mint az adott génnel nem rendelkezők [9].

Serdülőkorban az inzulinérzékenység 25-50\%-os csökkenése is bekövetkezhet, mely elhízottakban még kifejezettebb mértékű. Saját vizsgálatunkban elhízott kaukázusi gyermekekben kimutattuk, hogy a serdülőkori inzulinrezisztencia mértéke, illetve megjelenése összefüggést mutat a fokozott cardiovascularis kockázat jelenlétével. A metabolikus szindrómás, vagyis fokozott cardiovascularis kockázatú obes gyerekek esetében az anyagcsere-egészséges, kockázatmentes elhízottakkal összevetve a serdülést megelőzően a postprandialis inzulinrezisztencia dominált, míg a pubertás után a praeprandialis inzulinrezisztencia volt nagyobb mértékű. Emellett a cardiovascularisan veszélyeztetett, elhízott, prepubertáskorú gyermekekben a dyslipidaemia is kifejezettebb mértékűnek bizonyult [21]. Az elhízás típusa gyermek-, serdülőkorban is jelentőséggel bír, ugyanis a visceralis régióban felszaporodott zsírszövet mértéke erősebben korrelál a HOMA-IR-indexszel, mint a subcutan régióban felhalmozotté. A visceralis régió zsírszövetének mértéke csökkent adiponektinszintekkel jár együtt, magasabb az interleukin-6 (IL-6) és a szövetiplazminogénaktivátor- 1 (PAIl) szintje is [22].

A gyerekkori tényezők közül független rizikót jelent a kis születési súly [9], melyet az esetek 70-90\%-ában az első életévekben úgynevezett behozó növekedés ( „catchup growth") és bizonyos anyagcsere-eltérések követhetnek [9]. Ha a gyermek egyéves korában még mindig átlag alatti súlyt mutat, nagyobb valószínúséggel alakul ki nála glükózanyagcsere-zavar, T2DM. Az is dokumentált ugyanakkor, hogy a túl korai behozó növekedés, illetve az ún. korai „adiposity rebound” erősen korrelál a későbbi túlsúllyal és az ennek következtében szintén kialakuló T2DM-mel. Azaz, bár a fejlődési út eltér, és más a mechanizmus, ezek a gyermekek mindenképpen veszélyeztetettek [23]. Többféle feltételezés van arra vonatkozóan, hogy mi állhat ennek hátterében: feltételezik, hogy ilyen esetekben a fetalis életben a géneknek valamiféle áthangolódása jöhet létre ( „a magzati programozás hipotézise”, avagy Barker-teória), és ún. „takarékos, túlélő" gének kerülnek előtérbe, melyek a későbbiekben az inzulinrezisztencia és a T2DM kialakulását okozhatják [24]. Számos tanulmány talált szignifikáns összefüggést az alacsony születési súly és a metabolikus szindróma egyes komponensei (emelkedett vérnyomás-, triglicerid-, inzulin- és HOMA-IR-értékek, nagyobb testtömegindex [BMI] és centrális obesitas, alacsonyabb adiponektinszint) között. Érdekes módon a behozó növekedést nem produkáló, kis születési súlyú gyermekeknél ezek az összefüggések nem mutathatók ki [24]. Más szerzők szerint nem maga a behozó növekedés az oka a későbbi inzulinrezisztencia és T2DM kialakulásának, hanem inkább a praenatalis átprogramozódás, amelynek célszerve a máj [25]; megint más feltételezések szerint a kis súlyú újszülöttek kevesebb izomszövettel jönnek a világra, 
mely izomsejtek számát a későbbiekben már nem lehet növelni, így eltolódik az egyensúly az izom- és a zsírszövet között, és ez vezet a későbbiekben az anyagcsere-kisiklásokhoz [23]. A perinatalis történések jelentőségét hangsúlyozza - a már említett Barker-teória mellett az ún. Csaba-féle hormonális imprinting elmélet is. Az utóbbi szerint a hormon és a receptor első találkozása során a receptor érési folyamatában egyfajta bevésődés ( „imprinting”) jön létre. A folyamat elmaradása vagy hibás lezajlása (például gyógyszerek, vegyszerek, környezetszennyezők hatása) életre szóló morfológiai, biokémiai, receptoriális és magatartási következményekkel járhat $[26,27]$. Mindezek mellett a szénhidrát-anyagcsere és következményei kialakulásában számos egyéb mechanizmus szerepe is felmerül $[28,29]$.

$\mathrm{Az}$ elmúlt években különös figyelem irányult a bél mikrobiológiai flórájának, a mikrobiomnak a szerepére az inzulinrezisztencia vonatkozásában. Számos adat szól amellett, hogy a mikrobiom változása szerepet játszik az inzulinérzékenységnek, a krónikus gyulladásos folyamatoknak, a zsírszövetmúködésnek és a testtömegváltozásnak a szabályozásában. Az adatok többsége állatkísérletes és szórványosabb felnőtt humán vizsgálatokra támaszkodik [30]. Figyelemre méltó azonban, hogy egy prospektív tanulmányban a csecsemókori mikrobiom összetétele (megnövekedett Bifidobacterium taxa és csökkent Staphylococcus aureus csíraszám) összefüggést mutatott a gyermekkorban kialakuló elhízással [31]. Egy közelmúltbeli, prepubertáskorú elhízott gyermekekben végzett, ún. metabolomikai vizsgálat is felveti, hogy a bélmikrobiota eltérései közrejátszhatnak a gyermekkori inzulinrezisztencia kifejlődésében [32]. Ezek az előzetes megfigyelések azonban - az ok-okozati összefüggések feltárása érdekében - természetesen további megerősítésre szorulnak.

\section{Diagnosztika}

A diagnosztikában az „arany standard” az ún „hyperinsulinaemiás euglykaemiás clamp” technika [9], ennek nehézkes volta miatt azonban más technikák is használatosak. Ilyen az intravénás glükóztolerancia-teszt [9], mely kiküszöböli a glükózoldat felszívódásából származó bizonytalanságokat, és az inzulintolerancia-teszt [9], melynek során intraperitonealisan adott inzulin adása mellett figyelik a szisztémás glükózclearance-t. Az utóbbi hátránya a hypoglykaemia és az ellenregulációs hormonválasz, mely befolyásolhatja az eredményeket. Ezek a tesztek invazívak és túl komplexek a napi klinikai gyakorlathoz. Emiatt számos szerző különféle helyettesítő indexeket javasol, melyek közül a gyermekkori vizsgálatokban az éhomi vérmintából meghatározható plazmainzulinszint, a HOMA-IR-index, a QUICKI, a McAuley-index és a triglicerid/HDL-C hányados került alkalmazásra. A fentieken kívül néhány vizsgálatban az orális glükóztolerancia-teszt (OGTT) alkalmával mért glükóz- és inzulinszinteket, illetve az ezekből számolt paramétereket használták az inzulinrezisztencia mérésére.

Nehezíti a vizsgálati módszerek és paraméterek diagnosztikus használhatóságának megítélését az, hogy kevés megfelelő gyermekkori referenciaadat áll rendelkezésre az irodalomban. Léteznek ugyan gyermekkori vizsgálatok alapján javasolt „cut-off” értékekról megjelenő cikkek, de ezek sokszor igen kis mintával dolgoznak ahhoz, hogy használható normálértékeket lehessen meghatározni, ezenkívül ezek általában egy bizonyos populációra korlátozódnak mind etnikai, mind korcsoportos szempontból [3-8]. Mint korábban is utaltunk rá, az inzulinérzékenység fiziológiásan is korfüggő jelenség, ami kisebb mértékben ugyan, de érvényes az éhomi vércukorértékekre is. Problémát jelent az értékek összevetésében a tanulmányokban használt különböző laboratóriumi technikák eltérő volta is $[3,6,8]$.

Az éhomi inzulinszint meghatározása a legegyszerúbb módszer, mely mutatja a kompenzatorikus hyperinsulinaemiát és a máj inzulinmetabolizmusát; hátránya, hogy nem veszi figyelembe az aktuális vércukorértéket, gyermekekben pedig nem korrelál az inzulinrezisztencia mértékével, és nincsenek megbízható referenciaértékek $[33,34]$.

A HOMA-IR-index már figyelembe veszi az éhomi vércukorszintet, értéke jól korrelál az inzulinrezisztencia mértékével, jól tükrözi a máj glükózprodukciója és az inzulinválasz közti interakciót, a máj és a pancreas-bétasejtek közti 'feedback' kapcsolat állapotát. Előnye, hogy ugyanazon egyén követése során ismételten vizsgálva, összevethető értékeket szolgáltat, és a legtöbb gyermekkori vizsgálatban ezt a paramétert alkalmazzák. Az index komputerre adaptált változata az ún. HOMA2-index, mely nem lineáris módon számol, és különbséget tud tenni a hepaticus és a perifériás glükózrezisztencia között. Hátránya, hogy gyermek- és serdülőkorú egyéneken nagyon kevés tapasztalattal rendelkezünk. Mindazonáltal a HOMA-IR-index tekintetében sincsenek megbízható és elfogadott gyermekkori referenciaértékek, bár a legtöbb közlés ezzel a paraméterrel kapcsolatos.

Allard és mtsai Kanadában nagyszámú reprezentatív mintavételezés alkalmával a HOMA-IR felső határát nemek és életkorok szerint eltérônek találták, ami az inzulinérzékenység serdülőkori változását tükrözi. Vizsgálatukban a HOMA-IR 95-ös percentilisértéke 9 éves fiúkban és lányokban 1,88 és 2,07, 13 éves fiúkban és lányokban 3,28 és 3,86, 16 éves fiúkban és lányokban 3,31 és 3,10 értékünek adódott [4].

Shashaj és mtsai 2015-ben 2753, 2-18 éves kaukázusi gyermeken végzett vizsgálat során kor-, nem- és BMIspecifikus HOMA-IR-index-percentiliseket számoltak. A 75-ös percentilisértéket alkalmasnak találták a kardiometabolikus kockázat felismerésére, mely a teljes populációban 3,02, a normál testsúlyúakban 1,68, az elhízottakban pedig 3,42 értékünek adódott (a HOMA-IR „cut-off” értéke) [35]. 
Arellano-Ruiz és mtsai nemrégiben közel 9000 gyermeket felölelő 6 közlemény metaanalízise során a HOMA-IR metabolikus szindrómára utaló határértékét elemezték. A szerzők hasznosnak ítélték a HOMA-IRindexet az inzulinrezisztencia megítélésére, ugyanis azt találták, hogy a metabolikus szindróma komponenseinek megjelenésével a HOMA-IR értéke paralel növekszik. Az elemzésben - nemi és korosztályos bontás nélkül - a 95\%-os megbízhatósággal jellemezhető határértékek 2,30-tól 3,54-ig terjedtek, ami szintén széles tartomány, a szerzók azonban az ezen belüli értékeket gyermek- és serdülőkorban megbízhatónak tartják a metabolikus szindróma diagnosztikájában [22].

Van der Aa 103 releváns irodalmi közlés szisztematikus áttekintése során azt találta, hogy az egyes közlések a HOMA-IR felső határértékét gyermek- és serdülőkorban igen széles tartományban, 1,4 és 5,6 között adták meg. Ez alapján az inzulinrezisztencia egységes diagnosztikája érdekében a kórosan emelkedett HOMA-IR határértékének konszenzuson alapuló megállapítását szorgalmazza [36].

AZ IDEFICS-kohorszvizsgálat szerzői egészséges, európai, prepubertáskorú gyermekeket vizsgálva állítottak fel percentiliseket az éhomi inzulin-, glükóz-, $\mathrm{Hb}_{\mathrm{Alc}^{-}}$ és HOMA-értékekre. Ennek kapcsán kimutatták, hogyan változik ezek értéke a korral és a nemmel, és azt találták, hogy az elhízott gyermekek - különösen a magasabb korosztályú csoportokban - a HOMA-index és az inzulinszint alapján kifejezetten a magas, 95-ös percentiliscsoportokba tartoztak, az éhomi glükózérték tekintetében azonban ez nem volt megállapítható. Bár a BMI ismerten befolyásolja a HOMA értékét, a prepubertáskorú gyermekekben ez az összefüggés gyengébbnek bizonyult, mint idősebb életkorban. $\mathrm{A} \mathrm{Hb}_{\mathrm{Alc}}$-érték standard markerként ebben az egészséges csoportban nem bizonyult relevánsnak [1].

A QUICKI a HOMA-indexhez hasonlóan az éhomi glükóz- és inzulinértékekből számol, azzal a különbséggel, hogy az éhomi inzulin és glükóz logaritmusai összegének inverzét alkalmazza. Ebból adódóan a HOMAindex és a QUICKI alkalmazhatósága nem különbözik.

Gyermekkorban egyes szerzők javasolják markerként használni a triglicerid/HDL-C hányadost. Egy 1452 fős mintán vizsgálva, nagyon erôs pozitív korrelációt találtak ezen hányados és az inzulinszekréció, -szenzitivitás között különféle etnikumú gyermek-serdülő csoportokban [37]. E paraméter használhatóságára azonban még további vizsgálatok szükségesek.

Az éhomi inzulin- és trigliceridszint bevonásával számolható a McAuley-index, mely fiatal felnőtteken magas szenzitivitású és specifitású indexnek bizonyult az inzulinszenzitivitás felmérésére, ám értékelhető gyermekkori tapasztalat még nem áll rendelkezésre [38].

Újabban alkalmazásra kerülnek olyan paraméterek, melyek az OGTT során meghatározott plazmainzulinés -glükózértékekből számíthatók. Ilyen a Matsuda-féle teljestest-inzulinszenzitivitási index (WBISI), a Matsuda- index [39], a Soonthornpun által leírt inzulinszenzitivitási index (ISI) [40] vagy az egyéb inzulinrezisztenciaindexek (Belfiore, Stomwoll) [4l]. Ezek a módszerek felnőtt egyénekben kerültek validálásra, de ígéretesnek mutatkoznak gyermek-, illetve serdülőkori vizsgálatokban is, használhatóságuk megítélésére azonban még nem áll rendelkezésre kellő számú adat ebben a korosztályban. Saját vizsgálatainkban az inzulinrezisztencia praeprandialis mérésére a HOMA-IR-indexet, a postprandialis állapot megítélésére az OGTT során nyert inzulin- és glükózgörbék alatti területek hányadosát alkalmaztuk [21].

\section{Az inzulinrezisztencia következményei, metabolikus szindróma}

A gyermek- és serdülőkori inzulinrezisztencia számos kórállapot kialakulásához járul hozzá, melyek a későbbi életkorban népegészségügyi problémaként jelentős betegség- és egészséggazdasági terhet jelentenek. Ilyen kórállapotok a szénhidrát-anyagcsere rendellenességei, a dyslipidaemia, a magas vérnyomás - melyek a metabolikus szindróma komponenseiként a korai atherosclerosis és a fokozott cardiovascularis kockázat megtestesítői -, valamint a PCOS és a nem alkoholos májsteatosis (NAFLD). A következmények kialakulásának központi eleme az elhízás. Az inzulinrezisztencia a kulcs az elhízás és a következményes kórállapotok között, melyek fokozott cardiovascularis halálozásban nyilvánulnak meg [1].

A szénhidrátanyagcsere-eltérések kialakulásában az inzulinérzékenység megváltozása fontos szerepet játszik. A csökkent inzulinszenzitivitás, a hyperinsulinaemia és a béta-sejt-diszfunkció a T2DM kialakulásának alapvető elemei $[9,42]$. Egy nemrég megjelent tanulmány szerint elsődleges a béta-sejt-diszfunkció, melyet tovább ront a jelen levő csökkenő inzulinszenzitivitás, így vezetve a csökkent glükóztolerancia kifejlődéséhez. Az azonban még mindig nem bizonyított, hogy az inzulinrezisztencia serdülőkori jelenlétéből biztosan meg lehet-e jósolni a később megjelenő csökkent glükóztoleranciát vagy T2DM-et [42].

Inzulinrezisztencia jelenlétében dyslipidaemia is kialakul, mely a cardiovascularisan veszélyeztetett elhízott gyermekekben már a serdülőkor előtt kifejezett formában megjelenhet [16]. Emelkednek a trigliceridszintek, és csökkennek a HDL-C-szintek, tovább növelve a cardiovascularis rizikót. A magas inzulinszintek fokozzák a máj trigliceridszintézisét. Az inzulinrezisztencia jelenléte csökkenti az antiatherogen hatású adiponektinszinteket is, így fokozva az atherosclerosis kockázatát [9]. Az inzulinrezisztencia felelős a máj-, az izom-, a zsírszövet és a pancreas zsírakkumulációjáért, a NAFLD megjelenéséért, ami jól korrelál az inzulinnak a perifériás szövetekben és a májban érvényesülő rezisztenciájával és - úgy tûnik - az abdominalis zsírfelhalmozódással is.

A hypertensio megjelenése sokrétű: egyrészt magának az inzulinnak az érfalra, illetve a nátrium-visszaszívásra 
gyakorolt hatása, az inzulinrezisztencia jelenlétében kialakult csökkent natriureticuspeptid-termelődés, az atherosclerosis következtében létrejövő érfali „stiffness”, az endotheliumdependens dilatáció csökkenése mind hozzájárul a vérnyomásértékek emelkedéséhez. Inzulinrezisztencia jelenlétében inflammatorikus citokinek jelennek meg, krónikus gyulladást létrehozva. A gyulladás - inzulin stimulálta növekedési faktorokkal együtt - károsítja az érfalakat, elősegítve a cardiovascularis rizikó növekedését. A fenti jelenségek kialakulása gyermek- és serdülőkorban is kimutatható, de kapcsolatot fedeztek fel az inzulinrezisztencia és egyéb ágensek, mint például a retinolkötő protein-4, illetve a leptin között is [9].

PCOS-adolescens lányokban gyakran látunk súlyos inzulinrezisztenciát, a glükózanyagcsere következményes kisiklásával, csökkent glükóztoleranciával vagy T2DMmel. A PCOS-ban szenvedő lányok az elhízástól függetlenül is veszélyeztetettek inzulinrezisztenciára és metabolikus szindrómára. A PCOS patogenezise még nem tisztázott kellő mértékben, genetikai és környezeti tényezők egyaránt szerepet játszanak a kialakulásában, és számos adat támasztja alá az elhízás és az inzulinrezisztencia szerepét a kóroki folyamatokban.

Az elhízott gyerekek és serdülők, akiknél NAFLD mutatkozik, inzulinrezisztensek, de a NAFLD megjelenése sok esetben meg is előzi az inzulinrezisztencia kialakulását. Danforth [43] hipotézise szerint az ok a nem elegendő subcutan zsírszövet mennyisége, mely miatt a zsír további felhalmozódása a visceralis régiókban, a májban történik. Ahogy nő a visceralis/subcutan zsírszövet aránya, annál magasabb fokú inzulinrezisztencia alakul ki. A fokozott zsírfelhalmozódás felborítja a lipolízis, illetve az inzulinszekréció szabályozását, így okozván fontos ok-okozati összefüggést a NAFLD és a T2DM megjelenése között. Normálkörülmények között az inzulin az adipocyták lipolízisének gátlásával csökkenti a máj glükózprodukcióját, így védve a májat a túlzott zsírfelhalmozástól. NAFLD-ben szenvedő betegekben ez a szabá- lyozás felborul. A NAFLD megjelenésének és súlyosságának kialakulásában genetikai faktorok is közrejátszanak. Az elképzelések szerint a „takarékos” géneket hordozók, akik békeidőben nagyobb energiakészletet akkumuláltak a májban, képesek voltak túlélni a háborúkat, az éhezéseket, és ezen génhordozók túlélése hozzájárult a metabolikus szindróma békeidős pandémiájához.

Mindezen kórállapotok együttesen adják a metabolikus szindróma fogalmát: ez tulajdonképpen azon rizikófaktorok együttes fennállásának gyưjtője, amely felhívja a figyelmet a várható cardiovascularis megbetegedések fokozott megjelenésére. A metabolikus szindróma kialakulásában többféle tényező játszik közre: a szülők metabolikus szindrómája, bizonyos génpolimorfizmusok növelik a rizikót a leszármazottakban. Serdülőkorban a férfinem jelent rizikót, de ez a különbség a felnőttkorra eltünik. A rassz tekintetében a hispán etnikumúak veszélyeztetettebbek a kaukázusiaknál és az afroamerikaiaknál. Ismert a fizikai aktivitás hiánya mint rizikófaktor. Mind a kései, mind a túl korai menarche fokozza a metabolikus szindróma veszélyét. Egyes tanulmányok szerint az excesszív fruktózfogyasztás is rontja az inzulinrezisztenciát. Egyes gyógyszerek, pszichotikumok használata, illetve például a bipoláris depresszió gyógyszerszedés nélkül is fokozott rizikót jelent. Minden olyan betegség, melynek részjelensége a súlygyarapodás - például a Klinefelter-szindróma - nem egészen ismert módon elhízás nélkül is kifejezett kockázatot jelent, és ebben a zsírszövet disztribúciója kiemelt jelentőségü [11, 14].

A metabolikus szindróma gyermekkori definiálására többféle kritériumrendszert is kidolgoztak [12]. A kritériumrendszerek célja azoknak a klaszterszerűen társuló kórállapotoknak az összegyuujjtése és értékelése, melyek kapcsán a később cardiovascularisan veszélyeztetett gyermekek kiemelésre kerülhetnek a nem veszélyeztetettek közül. Ezekben az egyes komponensek megléte vagy hiánya - az életkori tényezók figyelembevételével - kritériumrendszerenként eltér [12]. Egyes szerzők szerint nem

1. táblázat $\mid$ A gyermek- és serdülőkori metabolikus szindróma kritériumrendszere a Nemzetközi Diabetes Szövetség (IDF = International Diabetes Federation) ajánlása szerint

\begin{tabular}{|c|c|c|c|c|c|}
\hline & $\begin{array}{l}\text { Centrális obesitas } \\
\text { (etnikumspecifikus } \\
\text { derékkörfogat) }\end{array}$ & $\begin{array}{l}\text { Triglicerid } \\
(\mathrm{mmol} / \mathrm{l})\end{array}$ & $\begin{array}{l}\text { HDL-C } \\
(\mathrm{mmol} / \mathrm{l})\end{array}$ & $\begin{array}{l}\text { Vérnyomás } \\
\text { (Hgmm) }\end{array}$ & $\begin{array}{l}\text { Éhomi vércukor } \\
(\mathrm{mmol} / \mathrm{l})\end{array}$ \\
\hline $6-10$ év* & $\geq 90$-es percentílis & & & & \\
\hline 10-16 év & $\begin{array}{l}\geq 90 \text {-es percentílis v. } \\
\text { felnőtt ha kisebb }\end{array}$ & $\geq 1,7$ & $<1,03$ & $\begin{array}{l}\text { syst: } \geq 130 \\
\text { diast: } \geq 85\end{array}$ & $\begin{array}{l}\geq 5,6 * * \\
\text { v. ismert T2DM }\end{array}$ \\
\hline $\begin{array}{l}\text { 16+ } \\
\text { (felnőttkritériumok) }\end{array}$ & $\begin{array}{l}\text { fiú: } \geq 94 \mathrm{~cm} \\
\text { lány: } \geq 80 \mathrm{~cm}\end{array}$ & $\begin{array}{l}\geq 1,7 \\
\text { v. kezelt eltérés }\end{array}$ & $\begin{array}{l}\text { fiú: }<1,03 \\
\text { lány: }<1,29 \\
\text { v. kezelt eltérés }\end{array}$ & $\begin{array}{l}\text { syst: } \geq 130 \\
\text { diast: } \geq 85 \\
\text { v. kezelt hipertensio }\end{array}$ & $\begin{array}{l}\geq 5,6 * * \\
\text { v. ismert T2DM }\end{array}$ \\
\hline
\end{tabular}

Metabolikus szindróma: centrális obesitas + a további négy paraméter (triglicerid, HDL-C, vérnyomás, éhomi vércukor) közül bármelyik kettő kóros eltérésének fennállása.

*Metabolikus szindróma nem diagnosztizálható, pozitív családi anamnézis esetén a vizsgálatok elvégzendők.

* $5,6 \mathrm{mmol} / \mathrm{l}$ feletti vércukor esetén OGTT ajánlott, de nem szükséges a metabolikus szindróma diagnózisához.

HDL-C = magas sűrűségû lipoprotein-koleszterin; OGTT = orális glükóztolerancia-teszt; T2DM = 2-es típusú diabetes mellitus 
helyes, hogy a gyermekkori kóros határértékek megállapításakor csak az életkort és nem a serdülési stádiumokat veszik figyelembe, továbbá úgy tünik, hogy etnikumonként is eltérő referenciaértékeket kellene alkalmazni [11]. Definitív, egységes gyermekkori kritériumrendszer egyelőre nincs kidolgozva és elfogadva. A gyakorlatban a leginkább az International Diabetes Federation (IDF) gyermekkorra adaptált, korfüggő kritériumrendszere terjedt el (1. táblázat). Bár az irodalomban ennek hasznosságát a cardiovascularis rizikó és a T2DM jóslására egyes szerzők megkérdőjelezik, dokumentált, hogy a metabolikus szindróma komponenseinek gyermekkori jelenléte kétszeresére emeli a cardiovascularis és a T2DM-rizikót [14]. Az irodalomban a metabolikus szindróma gyermek- és serdülőkori prevalenciáját igen széles tartományban, 0,2\% és 38,9\% között írják le, aminek hátterében az eltérő kritériumrendszerek és a vizsgált csoportok különbözősége (például életkor, testtömeg, etnikum) állhat $[1,11,12]$.

\section{A szürés, a megelőzés és a kezelés lehetőségei}

Az inzulinrezisztencia és a hyperinsulinaemia megjelenése az elhízott gyermekekben számos kockázattal és következménnyel jár, ezért a szürés és a korai felismerés elméletileg fontos szempontként merül fel. Az eredményes szürés megvalósításához azonban pontos, megbízható, reprodukálható és könnyen kivitelezhető módszerre, megfelelő standardokra és hatékony kezelési lehetőségre lenne szükség. Ahogy a fentiekben tárgyaltuk, jelenleg nincsenek sem megbízható laboratóriumi módszerek, sem megbízható referenciatartományok, melyek alapján egyértelmúen besorolhatnánk a gyermekeket a veszélyeztetett csoportba. Emellett az inzulinrezisztencia izolált formájának gyógyszeres kezelésére sincs jelenleg egységes ajánlás. Mindezek alapján a klinikai gyakorlatban az inzulinrezisztencia rutinszerü szürése - beleértve az elhízott egyéneket is - nem indokolható. Az elhízás klinikai vizsgálattal viszonylag egyszerüen megállapítható, mely esetben az inzulinrezisztencia jelenléte kézenfekvő, így sem annak felismeréséhez, sem a testsúlycsökkentő intervenció eredményességének megállapításához nincs szükség laboratóriumi mérésre.

Az American Academy of Pediatrics (AAP) 2007. évi ajánlása szerint a klinikai tünetcsoportok együttállására kell figyelemmel lenni, melyek alapján tovább tájékozódhatunk. A fizikális vizsgálat során kiemelt jelentősége van az emelkedett vérnyomás és egyes kísérő tünetek (hepatomegalia, acanthosis nigricans) felismerésének, illetve laboratóriumi vizsgálatok alapján a dyslipidaemia jelenlétének. Elhízás, 95-ös percentilist meghaladó BMI esetén a laborvizsgálatok része kell, hogy legyen az éhomi lipidprofil- és vércukormérés, valamint a májfunkció és a vesefunkció ellenőrzése is ajánlott. Az éhomi lipidprofil alapján a genetikai dyslipidaemiák is látótérbe kerülhetnek. Az évenkénti vérnyomás-ellenőrzés minden elhízott gyermek esetén javasolt $[12,14]$. Bár a kulcsszerep az inzulinrezisztenciáé, nem javasolják ennek mérését éhomi inzulinmeghatározással. Pozitív anamnesztikus adatok és kockázati tényezők esetén (ld. korábban) a glükózanyagcsere megítélésére OGTT, illetve $\mathrm{a} \mathrm{Hb}_{\mathrm{Alc}}$ vizsgálata javasolt. Az utóbbi szerepe a diabetes és előállapotai diagnosztikájában azonban gyermekkorban még kevéssé tisztázott. Az AAP 2007 . évi javaslata alapján 10 éves életkor után, 85-ös percentilist meghaladó BMI felett, amennyiben még legalább két rizikófaktor jelen van, az éhomi vércukor-meghatározásra évente sort kell keríteni [12].

A jelenlegi prevenciós ajánlások szerint az anamnesztikus adatok alapján szükséges tájékozódni az anya gestatiós diabetese, elhízása vagy éppen alultápláltsága, terhesség alatti dohányzása felől, illetve az anyatejes táplálás hiányáról, melyek felhívhatják a figyelmet a fokozott rizikóra.

A megelőzés és a kezelés tekintetében továbbra is az életmód változtatása, a diéta és a fokozott fizikai aktivitás az elérhető és kézenfekvő megoldás. A fő cél elsősorban a cukrozott folyadékok lecserélése vízre vagy mesterséges édesítőszeres üdítőre, illetve a tévé/számítógép előtt töltött idő csökkentése. A fokozott fizikai aktivitás az inzuliszenzitivitás növelésével fejti ki kedvező hatását. Ehhez azonban az egész család pozitív hozzáállása, egészségügyi oldalról pedig folyamatos kontaktus szükséges ahhoz, hogy eredményt érjünk el [12]. Az elhízást gyakran kísérő depresszió és hangulatzavarok miatt a mentális segítségnyújtás eredményesebbé teheti az intervenciót, illetve az egyéb komorbiditások (például PCOS, menseszavarok, alvási apnoe) kezelésére is figyelmet kell fordítani [12].

Az AAP által 2011-ben kiadott, szakértői munkacsoport (Expert Panel on Integrated Guidelines for Cardiovascular Health and Risk Reduction in Children and Adolescents) által kidolgozott átfogó ajánlás részletes útmutatásokat ad a gyermekkori cardiovascularis kockázati tényezők bizonyítékokon alapuló megelőzéséről és kezeléséről [44]. Az ajánlás szerint a legerősebb („A” szintű) bizonyítékok az alábbiak mellett szólnak:

- a terhesség alatti és a serdülőkori dohányzás kerülése, - gyermekkorban a zsírmentes tej előnyben részesítése, - a koleszterinbevitel $300 \mathrm{mg} /$ nap alatt tartása,

- a napi kalóriabevitelból a zsírarány 30\% alatt tartása,

- a zöldség/gyümölcs bevitel növelése,

- kisgyermekkortól a napi rendszeres fizikai aktivitás propagálása,

- folyamatos étrendi nevelés,

- a szülők folyamatos edukálása,

- az LDL-koleszterin $190 \mathrm{mg} / \mathrm{dl}$ feletti értéke esetén sztatin- vagy epesavkötő kezelés,

- a szénhidrát-anyagcsere zavarainak keresése és kezelése,

- a vérnyomás monitorizálása és kezelése.

Az inzulinrezisztencia önmagában (T2DM, emelkedett éhomi vércukor, csökkent glükóztolerancia hiányá- 
ban) nem indikációja a gyógyszeres kezelésnek gyermekés serdülőkorban. Az elhízás mint inzulinrezisztens állapot kezelésére azonban felmerülhet a gyógyszeres terápia szükségessége. Az Endocrine Society által 2017 ben kiadott 'Pediatric obesity - clinical practice guideline' egyes válogatott esetekben indokolhatónak tartja a farmakoterápia alkalmazását [45].

Így a 16 éves kor feletti elhízottak esetében, ha az intenzív életmód-változtató program nem hozott kielégítő eredményt, az ajánlás a mellékhatásokat ismerő, tapasztalt szakemberek által irányított gyógyszeres kezelést - diabetes hiányában is - javasolhatónak tartja. A gyógyszerelést azonban fel kell függeszteni abban az esetben, ha 12 hetes kúra során nincs legalább 4\%-os BMI-csökkenés. Az ajánlás túlsúly esetén, illetve 16 éves kor alatt semmiképpen sem javasolja a gyógyszeres terápia bevezetését.

A gyógyszerek közül elsősorban a metformin jöhet szóba, mely csökkentheti a BMI-t, az inzulinrezisztenciát, az éhomi inzulin- és glükózszintet, a táplálékfelvételt, egyes tanulmányok szerint a vérnyomást, és kedvezően hat a lipidprofilra [46]. A készítmény 10 év feletti gyermekekben T2DM kezelésére alkalmazható. A metformin praediabeteses felnőttek esetében hatásosnak bizonyult a T2DM kialakulásának megelőzésében, így emelkedett éhomi glükóz esetén és a csökkent glükóztolerancia eseteiben rendelkezik indikációval [47]. Mindazonáltal a gyermek- és a serdülőkor vonatkozásában egyelőre kevés megerősítő adat áll rendelkezésre, ezért 18 éves kor alatt a metformin fogyasztószerként, illetve praediabetesben jelenleg nem rendelkezik indikációval.

A glükagonszerû peptid-1 (GLPl)-analógok szintén csökkentik az inzulinrezisztenciát, és a liraglutid serdülőkben T2DM kezelésére már az Egyesült Államokban és az Európai Unióban is törzskönyvezésre került. Elhízott, inzulinrezisztens, de nem diabeteses serdülőkben történő vizsgálata során azonban hatása a BMI-re, az éhomi vércukor- és inzulinszintre és a $\mathrm{Hb}_{\mathrm{Alc}}$-értékre nem bizonyult szignifikánsnak, így szerepe jelenleg még nem ítélhető meg a gyermek- és serdülőkorban [48].

A nátrium-glükóz-kotranszporter 1-es és 2-es típusa (SGLT1, SGLT2), a glükóz bélből való felszívódásáért, illetve a vesében való visszaszívásáért felelős enziminhibitorok csoportjába tartozó készítmények javítják a glykaemiás kontrollt felnőttkori 1-es és 2-es típusú diabetesben, de hatásuk egyelőre nem ismeretes inzulinrezisztenciában, illetve gyermekkorban [49].

A dipeptidil-peptidáz-4 (DPP4)-inhibitorok új per os antihyperglykaemiás szerek, melyek az inkretinszintgátlás csökkentésén keresztül serkentik az inzulinválaszt, ám gyermekkori adatokkal jelenleg még nem rendelkezünk [50].

A szibutramin és az orlisztát súlycsökkentést és inzulinszenzitivitást javító készítmények, amelyek az Egyesült Államokban FDA-engedéllyel rendelkeznek gyermekkori alkalmazásra is. A szibutramint mellékhatások miatt kivonták a forgalomból, az orlisztát 12 éves kor felett továbbra is alkalmazható. Az Európai Unióban egyik készítmény sem rendelkezik gyermekkori alkalmazásra vonatkozó EMA-engedéllyel, így terápiás alkalmazása nem jön szóba ebben a korosztályban.

A gyomorszúkítő műtétek tekintetében gyermekkori adatok még nem állnak rendelkezésre kellő mennyiségben. Mindazonáltal ígéretes eredményekről számolnak be egyes munkacsoportok, melyek morbid obes adolescensek esetében a metabolikus szindróma statusában a mútét után 6 hónappal 59\%-os, 12 hónappal 69\%-os csökkenést dokumentáltak [14]. Gyermekkorban azonban a sebészi beavatkozásokat a jelenlegi ajánlások nem támogatják.

\section{Következtetések}

Az inzulinrezisztencia genetikai és környezeti tényezők hatására kialakuló állapot, mely az inzulin hatásának csökkenésében nyilvánul meg. Hátterében számos tényező ismeretes, a leggyakrabban azonban gyermekkorban is elhízáshoz társulva jelentkezik, és következményei közül a fokozott cardiovascularis kockázat és a felnóttkori halálozás a legnagyobb figyelmet érdemlő népegészségügyi szempont. Ma már a rizikófaktorok széles tárháza ismeretes, melyek közül a legtöbb gyermekgyógyászati adat a születési súlyra, a postnatalis és a gyermekkori súlygyarapodásra, valamint a pubertás etnikai jellegzetességeire vonatkozik, de egyes felmérések felvetik a csecsemőkori mikrobiom szerepét is.

Az inzulinrezisztencia pontos laboratóriumi diagnosztikájának a gyermekkorban számos akadálya van, melyek közül a legfontosabb, hogy nincs egységes kritériumrendszer, és az inzulin hatására vonatkozó vizsgálati paraméterek gyermekkorra érvényes normálértékei sincsenek meghatározva. A legtöbb adat gyermek- és serdülőkorban a HOMA-IR-index használhatóságára vonatkozik, mely azonban azon túl, hogy hiányzik a gyermekkori referenciatartománya, nem ad felvilágosítást a postprandialis állapotról, melynek vizsgálatához elkerülhetetlen a glükózterhelésre bekövetkezó inzulinválasz elemzése. Mindezek alapján szükséges lenne olyan módszerek konszenzus alapján történő meghatározása, melyek gyermekkorban alkalmazhatók. Ennek hiányában jelenleg gyermekkorban is az inzulinrezisztenciára utaló egyéb klinikai markerek adnak támpontot a fokozott cardiovascularis kockázat megítélésében. Ilyenek az elhízás mellett a dyslipidaemia, a vérnyomás és a glükózháztartás eltérései, melyek megítélésekor az adott paraméterek gyermekkori normálértékeit szükséges figyelembe venni. Emellett számos egyéb anamnesztikus (például születési súly, gyarapodási ütem) és klinikai entitást (például acanthosis, PCOS) lehet még felhasználni a veszélyeztetettek kiemelésére.

A jól ismert kedvezőtlen prognózis miatt az említett kórállapotok „cluster” jellegű együttállása esetén már a gyermekkorban beavatkozás szükséges. A primer prevenciónak már a terhesség alatt, azután pedig a kora 
gyermekkorban el kell kezdődnie (terhesség alatti táplálkozás, a dohányzás kerülése, az anyatejes táplálás forszírozása, a csecsemő- és kisdedtáplálás dietetikai ismeretei, különös tekintettel a cukros folyadékok fogyasztásának kerülésére). Szekunder prevencióként meg kell találnunk a veszélyeztetett gyermekeket, és gondozásba kell vennünk őket. A tercier prevenció, illetve a korai intervenciós lehetőség továbbra is a diétás és életmódi beavatkozásokat jelentik, melyek igen korlátozott hatásfokúak, elsősorban a compliance hiánya miatt. A farmakoterápiás lehetőségek és indikációk gyermekkorban - ritka kivételektől eltekintve - napjainkban igen korlátozottak, ez irányban a jövőben további, széles körű kutatásokra van szükség.

Anyagi támogatás: A vizsgálat a TÁMOP-4.2.1.B-10/2/ KONV-2010-0001. számú projekt, az Európai Unió és a European Social Fund támogatásával készült. A munkát támogatta a Magyar Diabetes Társaság.

Szerzői munkamegosztás: T. B., Ba. L.: A közlemény koncepciójának tervezése és kialakítása, a saját és a releváns irodalmi adatok elemzése, értékelése, a kézirat öszszeállítása, intellektuális tartalmának megalkotása. Bl. L., S. I., K. L.: A közlemény lényeges tartalmi szempontjainak kritikai véleményezése, revíziója. A cikk végső változatát valamennyi szerző elolvasta és jóváhagyta.

Érdekeltségek: A szerzőknek nincsenek érdekeltségeik.

\section{Irodalom}

[1] Peplies J, Jiménez-Pavón D, Savva SC, et al. Percentiles of fasting serum insulin, glucose, HbAlc and HOMA-IR in pre-pubertal normal weight European children from the IDEFICS cohort. Int J Obes (Lond). 2014; 38(Suppl 2): S39-S47.

[2] Singh B, Saxena A. Surrogate markers of insulin resistance: a review. World J Diabetes 2010; 1: 36-47.

[3] Grant DB. Fasting serum insulin levels in childhood. Arch Dis Child. 1967; 42: 375-378.

[4] Allard P, Delvin EE, Paradis G, et al. Distribution of fasting plasma insulin, free fatty acids, and glucose concentrations and of homeostasis model assessment of insulin resistance in a representative sample of Quebec children and adolescents. Clin Chem. 2003; 49: 644-649.

[5] Mellerio H, Alberti C, Druet C, et al. Novel modeling of reference values of cardiovascular risk factors in children aged 7 to 20 years. Pediatrics 2012; 129: e1020-e1029.

[6] Aradillas-García C, Rodríguez-Morán M, Garay-Sevilla ME, et al. Distribution of the homeostasis model assessment of insulin resistance in Mexican children and adolescents. Eur J Endocrinol. 2012; 166: 301-306.

[7] Masuccio FG, Lattanzio FM, Matera S, et al. Insulin sensitivity in prepubertal Caucasian normal weight children. J Pediatr Endocrinol Metab. 2009; 22: 695-702.

[8] Steene-Johannessen J, Kolle E, Anderssen SA, et al. Cardiovascular disease risk factors in a population-based sample of Norwegian children and adolescents. Scand J Clin Lab Invest. 2009; 69: 380-386

[9] Tagi VM, Giannini C, Chiarelli F. Insulin resistance in children. Front Endocrinol (Lausanne). 2019; 10: 342.
[10] Semple RK, Savage DB, Cochran EK, et al. Genetic syndromes of severe insulin resistance. Endocr Rev. 2011; 32: 498-514.

[11] Reinehr T. Metabolic syndrome in children and adolescents: a critical approach considering the interaction between pubertal stage and insulin resistance. Curr Diab Rep. 2016; 16: 8.

[12] Magge SN, Goodman E, Armstrong SC, et al. The metabolic syndrome in children and adolescents: shifting the focus to cardiometabolic risk factor clustering. Pediatrics 2017; 140: e20171603.

[13] Huang-Doran I, Tomlinson P, Payne F, et al. Insulin resistance uncoupled from dyslipidemia due to C-terminal PIK3RI mutations. JCI Insight 2016; 1: e88766.

[14] Wittcopp C, Conroy R. Metabolic syndrome in children and adolescents. Pediatr Rev. 2016; 37: 193-202.

[15] Ferrannini E, Natali A, Bell P, et al. Insulin resistance and hypersecretion in obesity. European Group for the Study of Insulin Resistance (EGIR). J Clin Invest. 1997; 100: 1166-1173.

[16] Ságodi L, Barkai L, Tombácz A, et al. Investigation of hyperinsulinaemia, insulin-like growth factor-1, insulin-like growth factorbinding protein- 1 , sex hormone binding-globulin in prepubertal girls and pubertal girls with a history of premature adrenarche. [A hyperinsulinaemia, az inzulinszerú növekedési faktor-1, inzulinszerú növekedési faktort kötő fehérje-1, a nemi hormont kötő globulin vizsgálata a prepubertáskorú és pubertáskorú leányoknál, akiknél praematurus adrenarche lépett fel.] Orv Hetil. 2003; 144: 67-72. [Hungarian]

[17] Tobisch B, Blatniczky L, Barkai L. Relationship between insulin resistance and puberty in children with increased cardiometabolic risk. [Inzulinrezisztencia és pubertás kapcsolata megnövekedett kardiometabolikus kockázatú gyermekekben.] Orv Hetil. 2011; 152: 1068-1074. [Hungarian]

[18] Goran MI, Bergman RN, Cruz ML, et al. Insulin resistance and associated compensatory responses in African-American and Hispanic children. Diabetes Care 2002; 25: 2184-2190.

[19] Whincup PH, Gilg JA, Papacosta O, et al. Early evidence of ethnic differences in cardiovascular risk: cross sectional comparison of British South Asian and white children. BMJ 2002; 324: 635.

[20] Arslanian SA, Saad R, Lewy V, et al. Hyperinsulinemia in AfricanAmerican children: decreased insulin clearance and increased insulin secretion and its relationship to insulin sensitivity. Diabetes 2002; 51: 3014-3019.

[21] Tobisch B, Blatniczky L, Barkai L. Cardiometabolic risk factors and insulin resistance in obese children and adolescents: relation to puberty. Pediatr Obes. 2015; 10: 37-44.

[22] Arellano-Ruiz P, García-Hermoso A, Cavero-Redondo I, et al. Homeostasis model assessment cut-off points related to metabolic syndrome in children and adolescents: a systematic review and meta-analysis. Eur J Pediatr. 2019; 178: 1813-1822.

[23] Eriksson JG, Forsén T, Tuomilehto J, et al. Early adiposity rebound in childhood and risk of type 2 diabetes in adult life. Diabetologia 2003; 46: 190-194.

[24] Cho WK, Suh BK. Catch-up growth and catch-up fat in children born small for gestational age. Korean J Pediatr. 2016; 59: 1-7.

[25] Cianfarani S, Geremia C, Germani D, et al. Insulin resistance and insulin-like growth factors in children with intrauterine growth retardation. Is catch-up growth a risk factor? Horm Res. 2001; 55(Suppl 1): 7-10

[26] Csaba G. Effect of endocrine disruptor phytoestrogens on the immune system: present and future. Acta Microbiol Immunol Hung. 2018; 65: 1-14.

[27] Csaba G. Hormesis and immunity: a review. Acta Microbiol Immunol Hung. 2019; 66: 155-168.

[28] Babik B, Peták F, Agócs S, et al. Diabetes mellitus: endothelial dysfunction and changes in hemostasis. [Diabetes mellitus: endotheldiszfunkció és haemostasiselváltozások.] Orv Hetil. 2018; 159: 1335-1345. [Hungarian]

[29] Vincze Á, Kertész L, Czeglédi E. The relationship between diabetes, stress and sleep problems in the light of the Hungarostudy 
2013 research data. [A diabetes, a stressz és az alvásproblémák kapcsolata a Hungarostudy 2013 kutatás adatainak fényében.] Orv Hetil. 2019; 160: 1872-1880. [Hungarian]

[30] Lee CJ, Sears CL, Maruthur N. Gut microbiome and its role in obesity and insulin resistance. Ann N Y Acad Sci. 2020; 1461: $37-52$.

[31] Kalliomäki M, Collado MC, Salminen S, et al. Early differences in fecal microbiota composition in children may predict overweight. Am J Clin Nutr. 2008; 87: 534-538.

[32] Mastrangelo A, Martos-Moreno GÁ, García A, et al. Insulin resistance in prepubertal obese children correlates with sex-dependent early onset metabolomic alterations. Int J Obes (Lond). 2016; 40: 1494-1502.

[33] Hwu CM. Measurements of insulin resistance in hypertension: where are we now? J Hum Hypertens. 2007; 21: 693-696.

[34] Lee S, Muniyappa R, Yan X, et al. Comparison between surrogate indexes of insulin sensitivity and resistance and hyperinsulinemic euglycemic clamp estimates in mice. Am J Physiol Endocrinol Metab. 2008; 294: E261-E270.

[35] Shashaj B, Luciano R, Contoli B, et al. Reference ranges of HOMA-IR in normal-weight and obese young Caucasians. Acta Diabetol. 2016; 53: 251-260.

[36] van der Aa MP, Knibbe CA, Boer A, et al. Definition of insulin resistance affects prevalence rate in pediatric patients: a systematic review and call for consensus. J Pediatr Endocrinol Metab. 2017; 30: 123-131.

[37] Giannini C, Santoro N, Caprio S, et al. The triglyceride-to-HDL cholesterol ratio: association with insulin resistance in obese youths of different ethnic backgrounds. Diabetes Care 2011; 34: 1869-1874

[38] McAuley KA, Williams SM, Mann JI, et al. Diagnosing insulin resistance in the general population. Diabetes Care 2001; 24: $460-464$.

[39] Matsuda M, DeFronzo RA. Insulin sensitivity indices obtained from oral glucose tolerance testing: comparison with the euglycemic insulin clamp. Diabetes Care 1999; 22: 1462-1470.

[40] Soonthornpun S, Setasuban W, Thamprasit A, et al. Novel insulin sensitivity index derived from oral glucose tolerance test. J Clin Endocrinol Metab. 2003; 88: 1019-1023.
[41] Brown RJ, Yanovski JA. Estimation of insulin sensitivity in children: methods, measures and controversies. Pediatr Diabetes 2014; 15: 151-161.

[42] Levy-Marchal C, Arslanian S, Cutfield W, et al. Insulin resistance in children: consensus, perspective, and future directions. J Clin Endocrinol Metab. 2010; 95: 5189-5198.

[43] Danforth E Jr. Failure of adipocyte differentiation causes type II diabetes mellitus? Nat Genet. 2000; 26: 13 .

[44] de Jesus, JM; Expert Panel on Integrated Guidelines for Cardiovascular Health and Risk Reduction in Children and Adolescents; National Heart, Lung, and Blood Institute. Summary report. Pediatrics 2011; 128(Suppl 5): S213-S256.

[45] Styne DM, Arslanian SA, Connor EL, et al. Pediatric obesity - assessment, treatment, and prevention: an Endocrine Society clinical practice guideline. J Clin Endocrinol Metab. 2017; 102: 709-757.

[46] Khokhar A, Umpaichitra V, Chin VL, et al. Metformin use in children and adolescents with prediabetes. Pediatr Clin North Am. 2017; 64: 1341-1353.

[47] Knowler WC, Barrett-Connor E, Fowler SE, et al. Reduction in the incidence of type 2 diabetes with lifestyle intervention or metformin. N Engl J Med. 2002; 346: 393-403.

[48] Danne T, Biester T, Kapitzke K, et al. Liraglutide in an adolescent population with obesity: a randomized, double-blind, placebo-controlled 5 -week trial to assess safety, tolerability, and pharmacokinetics of liraglutide in adolescents aged 12-17 years. J Pediatr. 2017; 181: 146-153.e3.

[49] Danne T, Biester T, Kordonouri O. Combined SGLTl and SGLT2 inhibitors and their role in diabetes care. Diabetes Technol Ther. 2018; 20 (Suppl 2): S269-S277.

[50] Guo H, Fang C, Huang Y, et al. The efficacy and safety of DPP4 inhibitors in patients with type 1 diabetes: a systematic review and meta-analysis. Diabetes Res Clin Pract. 2016; 121: 184191.

(Barkai László dr., Budapest, Bécsi út 96/b, 1034 e-mail: Barkai.L@t-online.hu)

\section{„Male secum agit aeger medicum qui heredem facit." (Publilius Syrus) (Maga ellen tesz a beteg, ha orvosát teszi örökösévé.)}

A cikk a Creative Commons Attribution 4.0 International License (https://creativecommons.org/licenses/by/4.0/) feltételei szerint publikált Open Access közlemény, melynek szellemében a cikk bármilyen médiumban szabadon felhasználható, megosztható és újraközölhetö, feltéve, hogy az eredeti szerző és a közlés helye, illetve a CC License linkje és az esetlegesen végrehajtott módositások feltüntetésre kerülnek. (SID_1) 